\title{
EFFECTS OF SOIL CONDITIONER ON WATER CONTENT OF SANDY SOIL AND PEANUT PRODUCTION UNDER DIFFERENT IRRIGATION RATES
}

\author{
Allam. A. Kh. ${ }^{1}$
}

\section{ABSTRACT}

Effects of soil conditioner on water content of sandy soil and peanut production under different irrigation rates were investigated during the two growing summer seasons of 2015 and 2016 at Abdel Moniem Reyad Village (Latitude $30^{\circ} 41^{\prime} 8^{\prime \prime} \mathrm{N}$, Longitude $30^{\circ} 18^{\prime} 0^{\prime \prime} \mathrm{E}$, and altitude of $7 \mathrm{~m}$ above sea level), Al-Bustan area, El-Beheira Governorate, Egypt. Also, the validity of a simulation model to predict changes in soil moisture contents with time as well as moisture distribution within the soil profile was tested. Four soil conditioner levels (SC0: control, SC1: 1 ton/fed, SC2: 2 ton/fed, and SC3: 3 ton/fed), and three irrigation rates (full irrigation: 100\% ETo, moderate deficit: $75 \%$ ETo and severe deficit: $50 \%$ ETo) were tested. Reference evapotranspiration (ETo) values were based on class A pan measurements. Peanut (Ismailia 2 cultivar) was used in the experiments. Results indicated that, the performance of the sprinkler irrigation system at the experimental site is considered acceptable. The additions of soil conditioner to the sandy soil led to decreasing the bulk density and saturated hydraulic conductivity values and increasing the saturated soil moisture contents, field capacity, welting point, available water, and air entry values. The tested simulation model proved to be accurate to predict changes in soil moisture contents with time as well as moisture distribution within the soil profile. Average seasonal values of applied irrigation water were 2986, 2240, and $1506 \mathrm{~m}^{3} / \mathrm{fed}$ for the 100, 75, and 50\% ETo treatments, respectively. The tested treatments significantly affected peanut yield and yield components parameters tested under the experimental conditions. Applying amount of irrigation water equals to $100 \%$ ETo with 2 ton/fed of hydro-gel soil conditioner produced the highest pod yield of 1.83 and 1.89 ton/fed and straw yields of 1.33 and 1.32 ton/fed from the peanut crop grown in sandy soil.

\footnotetext{
${ }^{1}$. Senior Res., Agric. Eng. Res. Inst., Agricultural Research Center (ARC), Egypt.
} 
Results indicated also that, an average water productivity value of 0.65 $\mathrm{kg} \mathrm{pod} / \mathrm{m}^{3}$ and $0.43 \mathrm{~kg} \mathrm{straw} / \mathrm{m}^{3}$ can be achieved from the interaction between $100 \%$ ETo $* \mathrm{SC}_{2}$ treatment. The results indicated that, in sandy soils of poor water retentive capacity, high yields of peanut crop can be obtained with the application of 2-3 ton/fed soil conditioner and irrigating with amount of water equals to $100 \%$ ETo.

Key words: Peanut, soil conditioner, polymer, irrigation rate, water productivity

\section{INTRODUCTIOPN}

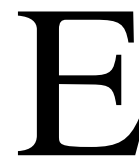
gypt lies in arid area and the agricultural activities depend heavily on irrigation. Annual rainfall is below $200 \mathrm{~mm}$ and agriculture depends almost totally on the water from a Nile river (55.5 Billion $\mathrm{m}^{3} /$ year) and nonrenewable ground water in the western desert. Therefore, efficient use of water has become extremely important in recent years since the main source of water has been declining causing shortages in water supply. Due to the increasing of population growth, Egypt reclaimed new areas in the desert to meet the deficit of agricultural production. The desert land, classified as sandy soils, is characterized by low water holding capacity, high infiltration and evaporation rates, and deep percolation losses that induce low water use efficiency, as well as low fertility levels (Al-Omran et al., 2010). The use of modern irrigation systems and amendment materials such as soil conditioners has helped improving crop production in the newly reclaimed areas. Soil amendments greatly affect the physical and chemical properties of the soils and could reduce the harmful effect of saline irrigation water (ElMaghraby et al., 1996, Beheiry et al., 1997, and Wassif et al., 1997). Using small amounts of natural or artificial products as soil conditioning help improving soil physical conditions by making air, water, and heat movements' optimal (Salem et al., 1990). The hydrogels or super absorbent polymer (SAP) materials are considered as important soil conditioners. Super absorbent polymers are compounds that absorb water and swell many times of their original size and weight. The SAP is applied into soil to create a water reserve near the roots and benefit agriculture (Zohuriaan-Mehr and Kabiri, 2008, and Han et al., 2010). The 
addition of SAP to the sandy loam soil resulted in a significant increase of the soil water retention compared to the control. Also, seed germination was significantly higher in SAP amended soil as well as the survival times of grass and wood plants were prolonged under water stress conditions as compared with the soil without SAP (Lixia et al., 2014). The effect of highest doses of hydrogel on water retention was best visible at $\mathrm{p}^{\mathrm{F}}$ values in the range of 1.5-2 bars. The highest doses increased retention capacity by $260 \%$ when added in the concentration of $4 \mathrm{~g} \cdot \mathrm{dm}^{-3}$ and by $440 \%$ at the dose of $6 \mathrm{~g} \cdot \mathrm{dm}^{-3}$. At $\mathrm{p}^{\mathrm{F}}$ values varied between 0 and 1.5, water retention increased by 42 and $170 \%$ at doses of 4 and $6 \mathrm{~g} \cdot \mathrm{dm}^{-3}$, respectively, in comparison with the control (Leciejewski, 2009). The hydrogels are water-retaining polymers that can absorb water about 100 to 150 times of their own weight. A significant fraction of this absorbed water is available to plants and thus, acts as an additional water reservoir for the soil-plant-air system (Bhardwaj et al., 2007). Hydrogels can absorb a volume of water 400 times their own weight (Bouranis et al., 1995), and due to this high water-holding capacity (Chatzoudis and Rigas 1999) they have been used successfully in agriculture and forest restoration as soil amendments (Viero et al., 2000; 2002, and Günes, 2007).

Peanut or groundnut (Arachis hypogaea L.) is one of the important legume crops of tropical and semiarid tropical countries, where it provides a major source of edible oil and vegetable protein. Groundnut kernels contain $47-53 \%$ oil and $25-36 \%$ protein. The crop is cultivated between $40^{\circ} \mathrm{N}$ to $40^{\circ} \mathrm{S}$ of the equator. Groundnut is a self-pollinated crop whereby flowers are produced above ground and, after fertilization, pegs move towards the soil, and seed-containing pods are formed and developed underneath the soil and helps maintain soil fertility through nitrogen fixation (Bogino et al., 2006; and Vara et al., 2011). The cultivated area of peanut in Egypt reached about 142857 feddans during 2016, and produced about 210000 metric tons of yield (USDA, 2016). The peak yield of peanut requires 500 to $700 \mathrm{~mm}$ of water. Peanut crop coefficient (kc) values for the initial stage (15 to 35 days) are 0.4-0.5, the crop development stage (30 to 45 days) are 0.7-0.8, the mid-season stage 
(30 to 50 days) are $0-95-1.1$, the late-season stage (20 to 30 days) are 0.70.8, and at harvest are 0.55-0.6 (Doorenbos and Kassam, 1986).

The objectives of the present study were to determine the effect of different levels of a locally manufactured soil conditioner and the rates of irrigation water on amounts of applied irrigation water, water consumptive used, water productivity, moisture properties of sandy soil and on the productivity of peanut crop. Also, to test the validity of a simulation model to predict changes in soil moisture contents with time as well as moisture distribution within the soil profile.

\section{MATERIALS AND METHODS}

Experimental site:

A field experiment was carried out during the two successive summer seasons of 2015 and 2016 at Abdel Moniem Reyad Village (altitude: 7m above sea level, latitude: $30^{\circ} 41^{\prime} 8^{\prime \prime} \mathrm{N}$, and longitude: $30^{\circ} 18^{\prime} 0^{\prime \prime} \mathrm{E}$ ), ElBustan area, El-Beheira governorate, Egypt. Some physical properties (particle size analysis, textural class, bulk density (BD), moisture content at field capacity (FC) and welting point (WP), and saturated hydraulic conductivity (ks)) and chemical properties (soil reacting $(\mathrm{pH})$, electric conductivity (EC), and soluble anions and cations) of the soil at the experimental site were determined. The measured parameters were determined according to Black et al. (1985) and presented in Tables (1) and (2). Soil bulk density was determined by using cylindrical cores (0.04 m long and $0.052 \mathrm{~m}$ I.D.) according to Blake and Hartge (1986).

Table (1). Some physical properties of the soil at the experimental site.

\begin{tabular}{|c|c|c|c|c|c|c|c|c|}
\hline \multirow{2}{*}{$\begin{array}{c}\text { Soil } \\
\text { depth } \\
(\mathrm{cm})\end{array}$} & \multicolumn{3}{|c|}{ Particle size $(\%)$} & \multirow{2}{*}{$\begin{array}{l}\text { Textura } \\
1 \text { class }\end{array}$} & \multirow{2}{*}{$\begin{array}{c}\mathrm{BD} \\
\left(\mathrm{Mg} \mathrm{m}^{-3}\right)\end{array}$} & \multirow{2}{*}{$\begin{array}{c}\text { FC } \\
\text { wt/ wt }\end{array}$} & \multirow{2}{*}{$\begin{array}{c}\text { WP } \\
\text { wt/ wt }\end{array}$} & \multirow{2}{*}{$\begin{array}{c}\mathrm{Ks} \\
\left(\mathrm{m} \mathrm{s}^{-1}\right)\end{array}$} \\
\hline & Sand & Silt & Clay & & & & & \\
\hline $0-20$ & 92.7 & 5.05 & 2.25 & Sandy & 1.59 & 0.143 & 0.062 & $4.15 \mathrm{E}-05$ \\
\hline $20-40$ & 93.5 & 4.36 & 2.14 & Sandy & 1.56 & 0.146 & 0.066 & $4.34 \mathrm{E}-05$ \\
\hline $40-60$ & 93.3 & 4.44 & 2.26 & Sandy & 1.58 & 0.145 & 0.064 & $4.67 \mathrm{E}-05$ \\
\hline
\end{tabular}

Table (2). Some chemical properties of the soil at the experimental site.

\begin{tabular}{|c|c|c|c|c|c|c|c|c|c|c|}
\hline \multirow{2}{*}{$\begin{array}{c}\text { Soil depth } \\
(\mathrm{cm})\end{array}$} & \multirow{2}{*}{$\begin{array}{c}\mathrm{pH} \\
(1: 2.5)\end{array}$} & \multirow{2}{*}{$\begin{array}{c}\mathrm{EC} \\
(\mathrm{dS} / \mathrm{m})\end{array}$} & \multicolumn{3}{|c|}{ Soluble cations (meq/l) } & \multicolumn{4}{|c|}{ Soluble anions (meq/l) } \\
\cline { 4 - 11 } & & & $\mathrm{Ca}^{2+}$ & $\mathrm{Mg}^{2+}$ & $\mathrm{Na}^{+}$ & $\mathrm{K}^{+}$ & $\mathrm{CO}_{3}{ }^{2-}$ & $\mathrm{HCO}_{3}{ }^{-}$ & $\mathrm{SO}_{4}{ }^{2-}$ & $\mathrm{Cl}^{-}$ \\
\hline $0-20$ & 7.98 & 1.31 & 3.2 & 2.5 & 6.3 & 0.7 & - & 3.7 & 2.2 & 6.7 \\
\hline $20-40$ & 8.11 & 1.33 & 3.1 & 1.9 & 6.2 & 0.9 & - & 3.5 & 2.4 & 6.2 \\
\hline $40-60$ & 8.15 & 1.34 & 3.0 & 2.1 & 6.3 & 0.8 & - & 3.7 & 2.1 & 6.5 \\
\hline
\end{tabular}




\section{Experimental design and tested treatments:}

A split plot design with three replicates was used to conduct the field experiment. The main plots represented four soil conditioner treatments, and the sub-plots were assigned for three irrigation rates.

Soil conditioner treatments (main plots):

SC0: without soil conditioner (control),

SC1: Applied soil conditioner at the rate of 1 ton/fed.

SC2: Applied soil conditioner at the rate of 2 ton/fed.

SC3: Applied soil conditioner at the rate of 3 ton /fed.

Irrigation rate treatments (sub-plots):

Full irrigation: $100 \%$ of reference evapotranspiration (ETo).

Moderate deficit: $75 \%$ of reference evapotranspiration (ETo).

Severe deficit: $50 \%$ of reference evapotranspiration (ETo).

\section{Cultural practices:}

The experimental field was prepared by plowing three times. Before the last plow, phosphorus fertilizer as triple superphosphate at $200 \mathrm{~kg} / \mathrm{fed}$ and $50 \mathrm{~kg} / \mathrm{fed}$ potassium fertilizer as potassium sulphate were applied prior to planting. Peanut cultivar (Ismailia 2) was used at rate of $45 \mathrm{~kg}$ seed/fed. Three seeds were planted per hill and the seedlings were thinned to two plants per hill 15 days after sowing (DAS). The planting and harvesting dates were 10, 15 May and 15, $21 \mathrm{Sep}$. in first and second seasons, respectively. Only the two central rows were used for sampling of each treatment.

Soil conditioner:

The soil conditioner used to amend the soil at the experimental site was manufactured as granules by the ARC, Soil Amendment Factory located at the research farm of Abdel Moniem Reyad Village, El-Bustan area, Egypt. The soil conditioner was made from hydrogel polymer powder mixed with taffla at 1:5 ratio. In the $1^{\text {st }}$ season only, soil conditioner was distributed according to the study rates and incorporated into the surface $20-30 \mathrm{~cm}$ layer of the soil before last plowing.

Irrigation system:

A solid-set sprinkler irrigation system was used. The components and parameters of the irrigation system network at the experimental site are 
summarized in Table (3). The discharge from the sprinkler nozzle was calibrated and the pressure was measured in the field using a hypodermic needle assembly and dial pressure gage as recommended by the ASAE standard (1988).

Table (3). Specifications of sprinkler irrigation network.

\begin{tabular}{|l|l|l|l|}
\hline Item & Specification & Item & Specification \\
\hline Sprinkler type & RC235 & Sprinkler wetted diameter & $24(\mathrm{~m})$ \\
\hline Nozzle diameter $\varnothing$ & $3.2(\mathrm{~mm})$ & PVC. lateral diameter & $63(\mathrm{~mm})$ \\
\hline Raiser height & $120(\mathrm{~cm})$ & Sprinkler spacing & $6 \times 12(\mathrm{~m})$ \\
\hline Steel riser diameter & $26.7(\mathrm{~mm})$ & PVC main line diameter & $110(\mathrm{~mm})$ \\
\hline Working pressure & $250(\mathrm{kPa})$ & Pump pressure head & $380(\mathrm{kPa})$ \\
\hline sprinkler flow rate & $0.61\left(\mathrm{~m}^{3} / \mathrm{h}\right)$ & Power of electric motor & $15(\mathrm{~kW})$ \\
\hline
\end{tabular}

\section{Sprinkler irrigation system evaluation:}

The irrigation system was evaluated before planting, at mid-season and after harvesting. Maintenance, was conducted before each growing season. Average water depth $\left(d_{a v}\right)$, average lower quarter depth $\left(d_{l q}\right)$, distribution uniformity $(D U)$, distribution efficiency $(C U)$, and water application efficiency $(E a)$ evaluation parameters were determine according to (Keller and Bliesner, 1990) and expressed by the following equations:

$$
\begin{aligned}
d_{a v} & =\frac{\sum X_{i}}{n} \\
d_{l q} & =\frac{\sum X_{\min 25 \%}}{n_{\min 25 \%}} \\
D U & =\frac{d_{n}}{d_{a v}} \times 100 \\
C U & =\left(1-\frac{\sum\left|X_{i}-X_{m}\right|}{X_{m} \times n}\right) \\
E a & =\frac{d_{l q}}{d_{a}} \times 100 .
\end{aligned}
$$

where:

$X_{i}=$ individual depth of water for each observation from the uniformity test $(\mathrm{mm})$.

$X_{m}=$ mean depth of water $(\mathrm{mm})$. 
$n=$ number of collection catch cans which were distributed in a grid system of $2 \times 1$ meter.

$\sum\left|X_{i}-X_{m}\right|=$ sum of the absolute deviation from the mean measurements

$d_{a}=$ average depth of irrigation water applied (sprinkler application rate for a given time $(\mathrm{mm})$.

The distribution uniformity test lasted half an hour, three quarter an hour and one hour under the operating pressure.

Crop water requirement (ETc):

Crop water requirement (ETc) was calculated as the sum of water loss through transpiration and soil evaporation based on Doorenbos and Pruitt (1992) and expressed as follows:

$$
\begin{gathered}
E T_{c}=E T_{o} \times K_{c} \quad m m \text { day }^{-1} \\
E T_{o}=E T_{p a n} \times K_{p a n} \quad m m \text { day }^{-1}
\end{gathered}
$$

where:

$E T_{o}=$ evapotranspiration of a reference plant under specified conditions calculated using the class A pan $\left(\mathrm{mm} \mathrm{day}^{-1}\right)$ at the experimental site.

$K_{c}=$ the crop coefficient values of peanut crop.

Epan $=$ measured class A pan values $\left(\mathrm{mm} \mathrm{day}^{-1}\right)$.

Kpan $=$ pan coefficient equals to 0.8 under experimental conditions.

Gross irrigation water depths (GIWD):

The gross irrigation water depths (GIWR) was calculated according to Brouwer et al. (1989) as follows:

$$
\begin{gathered}
G I W D=\frac{I_{r}}{E_{a} \times L R} \\
I_{r}=A \times E T_{c}
\end{gathered}
$$

where:

$I r=$ net irrigation depth $(\mathrm{mm})$.

$A=$ the plot area $\left(\mathrm{m}^{2}\right)$. 
$E_{a}=$ irrigation system application efficiency as calculated from system evaluation.

$L R=$ leaching requirements to control the soil salinity, estimated according to Doorenbos and Pruitt (1977) by the following formula for surface irrigation methods (including sprinklers) as:

$$
L R=\frac{E C_{w}}{5 E C_{e}-E C_{w}}
$$

where:

$E C_{e}=$ electrical conductivity of the soil saturation extract.

$E C_{w}=$ electrical conductivity of the irrigation water.

Irrigation duration $\left(T i_{s p r}\right)$ :

The irrigation time for the sprinkler irrigation system $\left(T i_{s p r}\right)$ was calculated according to Ismail (2002) as follow:

$$
T i_{s p r}=\frac{G I W D}{A_{r}} \times I n
$$

where:

$A r=$ sprinkler application rate $(\mathrm{mm} / \mathrm{h})$.

In $=$ irrigation intervals (day).

Peanut water consumptive use (WCU):

WCU values were estimated according to Simonne and Dukes (2010) as:

$$
W C U=\frac{\sum D\left(\theta_{v i}-\theta_{v f}\right)}{100 \times N D}
$$

where:

$D=$ thickness of the soil layer $(\mathrm{mm})$.

$\theta_{v i}=$ initial volumetric soil moisture content $(\%)$.

$\theta_{v f}=$ volumetric soil moisture content after irrigation $(\%)$.

$N D=$ No. of days between irrigations.

Soil moisture simulation:

Gravimetric soil samples, from soil surface down to $0.6 \mathrm{~m}$ depth at 0.20 $\mathrm{m}$ intervals were collected during the growing season from all treatments 
before and after each irrigation to determine water consumptive use (WCU, mm/day) or crop evapotranspiration (ETc). The distribution of measured soil moisture contents within the soil surface layer $(0-0.6 \mathrm{~m})$ was compared with the values predicted by a mathematical simulation model developed by Allam (2004). The simulation model was based on Richard's equation, developed from the two soil physical principles of Darcy's law and continuity equation. The equation governs the flow of water in the soil in terms of diffusivity form is reported by Miller and Klute (1967) as:

$$
\frac{\partial \theta}{\partial t}=\frac{\partial}{\partial x}\left(D(\theta) \frac{\partial \theta}{\partial x}\right)+\frac{\partial}{\partial y}\left(D(\theta) \frac{\partial \theta}{\partial y}\right)+\frac{\partial}{\partial z}\left(D(\theta) \frac{\partial \theta}{\partial z}\right)-\frac{\partial K(\theta)}{\partial z}
$$

where

$\theta$ is the volumetric soil water content in $\mathrm{m}^{3} \mathrm{~m}^{-3}$.

$t$ is time (min.).

$D(\theta)$ is the soil water diffusivity as a function of water content $\left(\mathrm{m}^{2} \mathrm{~min}^{-1}\right)$.

$K(\theta)$ is the unsaturated hydraulic conductivity as a function of water content $\left(\mathrm{m} \mathrm{min}^{-1}\right)$.

$x, y$ are the horizontal coordinates.

$z$ is the vertical coordinate which is considered to be positive downward.

The simulation model was used to simulate the distribution of irrigation water in the soil under the current study conditions. The simulation model was also used to evaluate the sprinkler irrigation system. The hydro-physical parameters of the soil at the experimental site needed as inputs to the simulation model were calculated using the following equation:

$$
\psi_{m}=\psi_{e}\left(\frac{\theta}{\theta s}\right)^{b}
$$

where:

$\psi_{m}, \psi_{e}$ are matric and the air entry potential.

$\theta, \theta_{s}$ are volumetric and the saturated water content and $b$ is a constant. 
Details of the simulation model, governing equations, and application examples are given in Allam (2004), Khalifa et al. (2004), and El-Shafei et al. (2008).

Yield and yield components:

At harvest, plant samples from an area of $1.2 \mathrm{~m}^{2}$ from the two central ridges were uprooted from each treatment randomly and topped to determine yields of seeds and straw per feddan and yield components (pod weight/plant, kernel weight/plant, and $100 \mathrm{kernel} /$ plant). Kernels crude protein percentage was calculated by analyzing samples at the Faculty of Agriculture, Alex. University. Shelling \% was calculated according to the following equation:

Shelling $\%=\frac{k \text { ernels weight /plant }}{\text { Pod weight / plant }} \times 100$

Water productivity (WP):

Water productivity $\left(\mathrm{kg} \mathrm{m}^{-3}\right)$ of peanut crop was calculated as proposed by Molden (2003).

$$
W P=\frac{Y}{I}
$$

where:

$Y$ is pods or straw yield in $\mathrm{kg} \mathrm{fed}^{-1}$ and $I$ is applied irrigation water in $\mathrm{m}^{3}$ fed $^{-1}$.

Statistical analysis:

The collected data were analyzed using Costat 6.311 Win. of CoHort Software (2005) statistical program. Average values from the three replicates of each treatment were interpreted using the analysis of variance (ANOVA). The Duncan's Multiple Range Test (SNK) was used for comparisons among different sources of variance.

\section{RESULTS AND DISCUSION}

\section{Field evaluation of the sprinkler irrigation system:}

The irrigation system was evaluated three times, before planting, midseason stage, and after harvesting. Evaluation results are presented in Table (4). Results showed that, the calculated Ea values varied from 
69.18 to $71.49 \%$ in the $1^{\text {st }}$ season and from 71.11 to $74.32 \%$ in the $2^{\text {nd }}$ season, respectively. According to the ASCE (1988), the obtained values are considered as acceptable values. Results indicated also that, the seasonal average distribution efficiency (CU) and distribution uniformity (DU) values were 91.1 and $85.2 \%$ in the $1^{\text {st }}$ season, and were 91.2 and $86.3 \%$ in the $2^{\text {nd }}$ season, respectively. The measured CU and DU values were in the recommended range (Benami and Ofen, 1984). As a result of these criteria, the performance of the sprinkler irrigation system is considered acceptable.

Table (4). Results of the field evaluation of sprinkle irrigation system.

\begin{tabular}{|l|l|l|l|l|l|l|}
\hline \multirow{2}{*}{ Testing time } & \multicolumn{3}{|c|}{ First season } & \multicolumn{3}{c|}{ Second season } \\
\cline { 2 - 7 } & Ea (\%) & CU (\%) & DU (\%) & Ea (\%) & CU (\%) & DU (\%) \\
\hline Before planting & 71.49 & 91.98 & 86.45 & 74.32 & 91.03 & 86.99 \\
\hline Mid-season & 69.18 & 91.07 & 85.18 & 71.11 & 92.79 & 87.88 \\
\hline After harvesting & 70.77 & 91.25 & 86.90 & 72.46 & 91.78 & 86.03 \\
\hline
\end{tabular}

Effect of soil conditioner treatments on some soil physical properties: In general, the addition of soil conditioner causes change in soil properties, especially the hydraulic properties. The effect of soil conditioner treatments on some soil physical properties is presented in Table (5) and illustrated in Figure 1. Results indicated that, increasing the rate of soil conditioner addition to sandy soil reduced the bulk density. The $\mathrm{BD}$ value of $\mathrm{SC}_{3}$ treatment (3 ton/fed) was $1.422 \mathrm{Mg} \mathrm{m}^{3}$ or about $10.6 \%$ less than that of $\mathrm{SC}_{0}$ treatment (control). Saturated soil moisture content $(\theta \mathrm{s})$ increased from 0.36 to $0.44 \mathrm{~m}^{3} \mathrm{~m}^{-3}$ or by $22 \%$ for the $\mathrm{SC}_{0}$ and $\mathrm{SC}_{2}$ treatments, respectively. There was no difference between $\theta \mathrm{s}$ values of $\mathrm{SC}_{2}$ and $\mathrm{SC}_{3}$ treatments. Results indicated also that, increasing soils conditioner rates reduced soil saturated hydraulic conductivity values. The $\mathrm{K}_{\mathrm{s}}$ values were $4.15 \mathrm{E}-5$ and $2.79 \mathrm{E}-5 \mathrm{~m} \mathrm{~s}^{-1}$ (32.8\% less) for the $\mathrm{SC}_{0}$ and $\mathrm{SC}_{3}$ treatments, respectively. The obtained results were in agreement with the findings reported by Bhardwaj et al. (2007), Andry et al. (2009), and Leciejewski (2009). Results revealed also that, both air entry $\left(\psi_{e}\right)$ and the constant $b$ values increased with increasing soil conditioner rates. For the $\mathrm{SC}_{0}$, the $\psi_{e}$ and $b$ values were $-0.344 \mathrm{~m}$ and 1.741 , while the same values for $\mathrm{SC}_{3}$ treatment were $-0.572 \mathrm{~m}$ and 2.156 . 
Figure 1. Effect of soil conditioner levels on water content at field capacity (FC) and permanent wilting point (WP) and available water (AW).

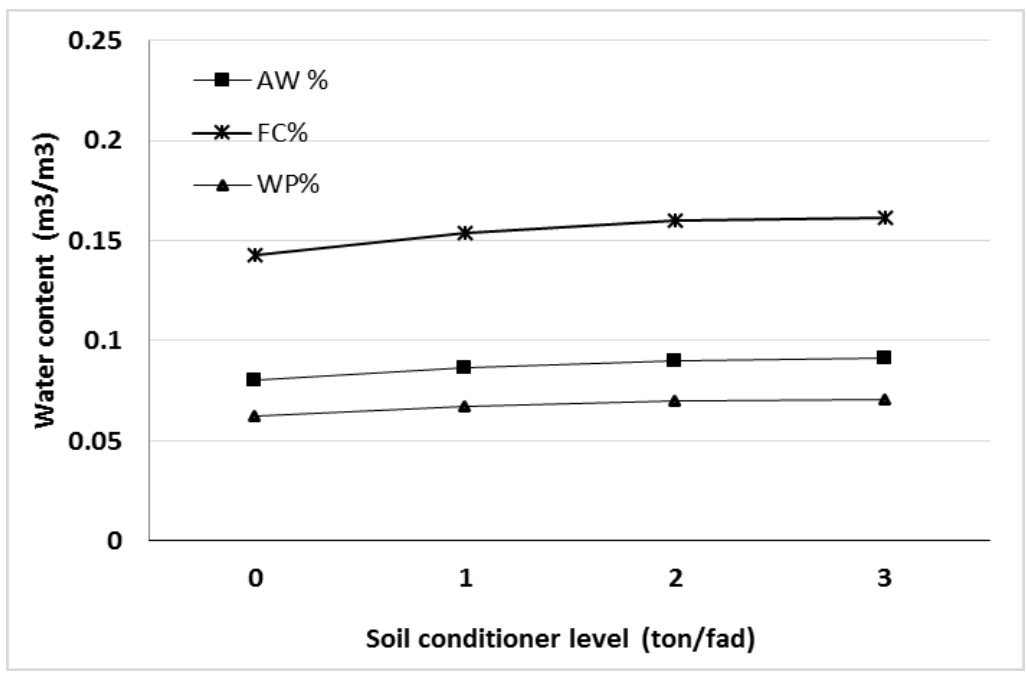

Table 5. Effect of soil conditioner treatments on some physical properties of soil at the experimental site.

\begin{tabular}{|l|c|c|c|c|c|}
\hline $\begin{array}{l}\text { Soil conditioner } \\
\text { treatments }\end{array}$ & $\begin{array}{c}\mathrm{BD} \\
\left(\mathrm{Mg} \mathrm{m}^{-3}\right)\end{array}$ & $\begin{array}{c}\Psi \mathrm{e} \\
(\mathrm{m})\end{array}$ & $\mathrm{b}$ & $\begin{array}{c}\theta \mathrm{s} \\
\left(\mathrm{m}^{3} \mathrm{~m}^{-3}\right)\end{array}$ & $\begin{array}{c}\mathrm{ks} \\
\left(\mathrm{m} \mathrm{s}^{-1}\right)\end{array}$ \\
\hline $\mathrm{SC}_{0}$ & 1.591 & -0.344 & 1.741 & 0.36 & $4.15 \mathrm{E}-5$ \\
\hline $\mathrm{SC}_{1}$ & 1.541 & -0.394 & 1.897 & 0.40 & $3.87 \mathrm{E}-5$ \\
\hline $\mathrm{SC}_{2}$ & 1.483 & -0.508 & 1.991 & 0.44 & $3.05 \mathrm{E}-5$ \\
\hline $\mathrm{SC}_{3}$ & 1.422 & -0.572 & 2.156 & 0.44 & $2.79 \mathrm{E}-5$ \\
\hline
\end{tabular}

The effect of soil conditioner rates on soil moisture contents is illustrated in Fig. 1. Results showed that, increasing SC rates increased soil moisture contents at field capacity (FC) and at wilting point (WP). The available water (AW) values increased from 0.7 to 0.9 for the $\mathrm{SC}_{0}$ and $\mathrm{SC}_{3}$ treatments, respectively.

\section{Effect of tested treatments on soil moisture distribution:}

The simulation model was used to predict soil moisture contents at different depths after different elapsed irrigation times. The model as validated by comparing the predicted soil moisture values with those gravimetrically measured in the field. A regression equation was 
developed to relate the predicted and the measured soil moisture values at different times ( $2 \mathrm{hrs}$ to $96 \mathrm{hrs}$ ) after irrigation. The developed relation is illustrated in Fig. 2. Results indicated that the value of determination coefficient $\left(\mathrm{R}^{2}\right)$ was 0.96 showing very close agreement between the predicted and measured values and the model is valid to predict soil moisture contents under the current experimental conditions scattering for both values.

Figure 2. Relationship between predicted and measured volumetric moisture contents.

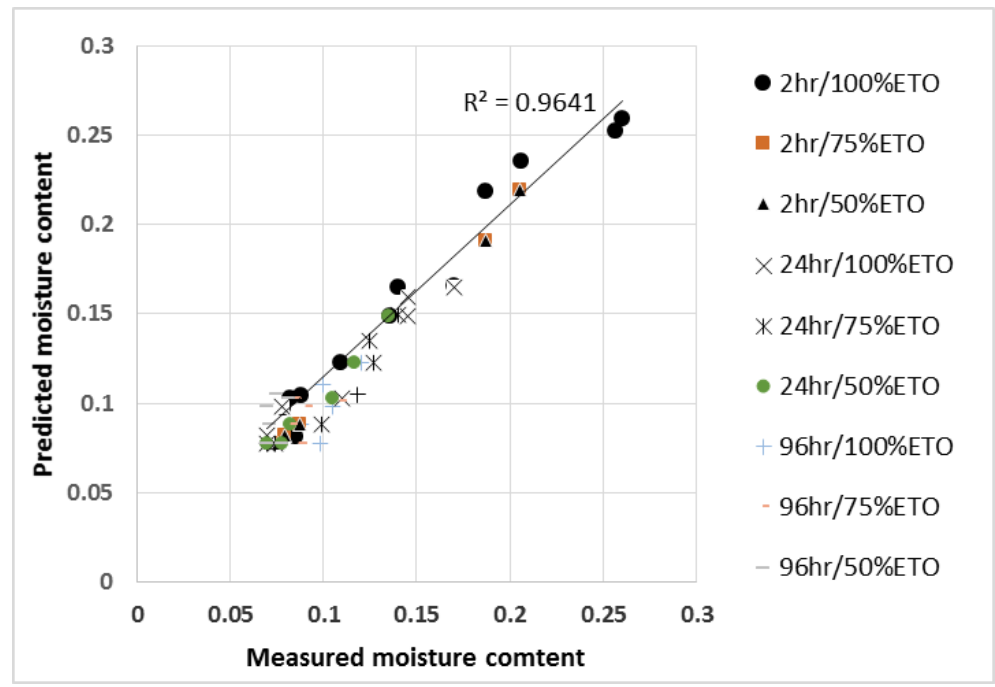

The distribution of measured and predicted soil moisture in the soil profile as affected by soil conditioner levels and applied irrigation rates after 2, 24, 72, and 96 hrs. from irrigation is illustrated in Figs. 3 and 4. Results indicated, in general, that there was a close agreement between the measured and predicted moisture contents under all tested treatments. Moisture contents were higher for the $\mathrm{SC}_{3}$ and $100 \%$ ETo treatments than the other treatments. After 2 hrs. from irrigation, moisture contents were high at the soil surface and decreased with depth. After $24 \mathrm{hrs}$., moisture contents decreased at the surface $(0-5 \mathrm{~cm})$ and increased in the $5-20 \mathrm{~cm}$ layer.

For the $100 \%$ ETo treatment, average soil moisture contents for the surface $20 \mathrm{~cm}$ layer were $0.129,0.139,0.145$, and $0.146 \mathrm{~m}^{3} / \mathrm{m}^{3}$ for the $\mathrm{SC}_{0}, \mathrm{SC}_{1}, \mathrm{SC}_{2}$, and $\mathrm{SC}_{3}$ treatments, respectively (Table 6). 
Table 6. Average soil moisture contents, $\theta$ lq (average soil moisture content for lower quarter), and $\Delta \theta$ (range of soil moisture content $\left(\mathrm{m}^{3} / \mathrm{m}^{3}\right)$ as affected by soil conditioner and irrigation treatments after 24,72 , and 96hrs. after irrigation.

\begin{tabular}{|c|c|c|c|c|c|c|c|c|c|c|c|c|c|c|c|c|c|c|c|}
\hline \multirow{3}{*}{$\underline{5}$} & \multirow{3}{*}{$\begin{array}{l}\text { Soil } \\
\text { depth } \\
\mathrm{cm}\end{array}$} & \multicolumn{9}{|c|}{$\mathrm{SC} 0$} & \multicolumn{9}{|c|}{$\mathrm{SC} 1$} \\
\hline & & \multicolumn{3}{|c|}{ 24hr after irrigation } & \multicolumn{3}{|c|}{$72 \mathrm{hr}$ after irrigation } & \multicolumn{3}{|c|}{ 96hr after irrigation } & \multicolumn{3}{|c|}{$24 \mathrm{hr}$ after irrigation } & \multicolumn{3}{|c|}{$72 \mathrm{hr}$ after irrigation } & \multicolumn{3}{|c|}{ 96hr after irrigation } \\
\hline & & $\theta$ av & $\theta \mathrm{lq}$ & $\Delta \theta$ & $\theta \mathrm{av}$ & $\theta \mathrm{lq}$ & $\Delta \theta$ & $\theta \mathrm{av}$ & $\theta \mathrm{lq}$ & $\Delta \theta$ & $\theta \mathrm{av}$ & $\theta$ lq & $\Delta \theta$ & $\theta \mathrm{av}$ & $\theta \mathrm{lq}$ & $\Delta \theta$ & $\theta$ av & $\theta 1 \mathrm{q}$ & $\Delta \theta$ \\
\hline \multirow{3}{*}{$\stackrel{8}{8}$} & $0-20$ & 0.129 & 0.119 & 0.0284 & 0.111 & 0.107 & 0.011 & 0.106 & 0.103 & 0.008 & 0.139 & 0.128 & 0.031 & 0.120 & 0.115 & 0.011 & 0.114 & 0.111 & 0.009 \\
\hline & $20-40$ & 0.102 & 0.089 & 0.028 & 0.110 & 0.103 & 0.020 & 0.108 & 0.102 & 0.015 & 0.111 & 0.096 & 0.043 & 0.119 & 0.111 & 0.022 & 0.116 & 0.110 & 0.016 \\
\hline & $40-60$ & 0.082 & 0.078 & 0.016 & 0.089 & 0.099 & 0.030 & 0.102 & 0.093 & 0.025 & 0.088 & 0.084 & 0.017 & 0.106 & 0.095 & 0.032 & 0.110 & 0.100 & 0.027 \\
\hline \multirow{3}{*}{$\stackrel{80}{i n}$} & $0-20$ & 0.109 & 0.099 & 0.023 & 0.093 & 0.090 & 0.009 & 0.089 & 0.086 & 0.007 & 0.116 & 0.107 & 0.025 & 0.101 & 0.097 & 0.009 & 0.095 & 0.092 & 0.007 \\
\hline & $20-40$ & 0.086 & 0.075 & 0.033 & 0.093 & 0.087 & 0.017 & 0.091 & 0.085 & 0.012 & 0.093 & 0.080 & 0.036 & 0.100 & 0.093 & 0.018 & 0.098 & 0.093 & 0.014 \\
\hline & $40-60$ & 0.079 & 0.076 & 0.013 & 0.083 & 0.074 & 0.025 & 0.086 & 0.078 & 0.021 & 0.085 & 0.082 & 0.015 & 0.089 & 0.080 & 0.027 & 0.092 & 0.084 & 0.022 \\
\hline \multirow{3}{*}{ ஜ̊ำ } & $0-20$ & 0.099 & 0. & 0 & 0. & 0 & 0 & 81 & & & & & 23 & 91 & 38 & & 37 & & 0.007 \\
\hline & $20-40$ & 0.084 & 0.075 & 0.031 & 0.085 & 0.079 & 0.015 & 0.083 & 88 & & 88 & 0.077 & 0.033 & 91 & 0.085 & 0.016 & 0.089 & .086 & 0.012 \\
\hline & $40-60$ & 0.075 & 0.076 & 0.012 & 0.081 & 0.076 & 0.017 & 0.078 & 0.075 & 0.019 & 0.080 & 0.077 & 0.013 & 0.087 & 0.082 & 0.018 & 0.084 & 0.077 & 0.022 \\
\hline & & \multicolumn{9}{|c|}{$\mathrm{SC} 2$} & \multicolumn{9}{|c|}{ SC3 } \\
\hline \multirow{3}{*}{$\stackrel{\circ}{8}$} & $0-20$ & 0.145 & 0.133 & 0.032 & 0.125 & 0.121 & 0.012 & 0.120 & 0.115 & 0.009 & 0.146 & 0.134 & 0.032 & 0.126 & 0.121 & 0.012 & 0.119 & 0.116 & 0.009 \\
\hline & $20-40$ & 0.116 & 0.100 & 0.045 & 0.124 & 0.116 & 0.022 & 0.122 & 0.116 & 0.018 & 0.116 & 0.101 & 0.045 & 0.125 & 0.117 & 0.023 & 0.122 & 0.116 & 0.017 \\
\hline & $40-60$ & 0.092 & 0.088 & 0.018 & 0.112 & 0.099 & 0.034 & 0.115 & 0.105 & 0.028 & 0.093 & 0.088 & 0.018 & 0.112 & 0.100 & 0.034 & 0.116 & 0.105 & 0.028 \\
\hline \multirow{3}{*}{$\stackrel{\circ}{i n}$} & $0-20$ & 0.122 & 0.112 & 0.027 & 0.105 & 0.101 & 0.010 & 0.100 & 0.097 & 0.008 & 0.123 & 0.113 & 0.027 & 0.106 & 0.102 & 0.010 & 0.101 & 0.098 & 0.008 \\
\hline & $20-40$ & 0.097 & 0.084 & 0.038 & 0.104 & 0.097 & 0.019 & 0.102 & 0.098 & 0.014 & 0.098 & 0.084 & 0.038 & 0.105 & 0.098 & 0.019 & 0.103 & 0.097 & 0.014 \\
\hline & $40-60$ & 0.088 & 0.085 & 0.015 & 0.094 & 0.083 & 0.028 & 0.097 & 0.087 & 0.023 & 0.089 & 0.085 & 0.015 & 0.094 & 0.084 & 0.028 & 0.097 & 0.088 & 0.023 \\
\hline \multirow{3}{*}{ ஜ̊ } & $0-20$ & 0.111 & 0.103 & 0.024 & 0.096 & 0.093 & 0.009 & 0.091 & 0.088 & 0.007 & 0.111 & 0.102 & 0.024 & 0.097 & 0.093 & 0.009 & 0.092 & 0.089 & 0.007 \\
\hline & $20-40$ & 0.092 & 0.080 & 0.034 & 0.095 & 0.089 & 0.017 & 0.093 & 0.087 & 0.013 & 0.096 & 0.081 & 0.035 & 0.096 & 0.089 & 0.017 & 0.094 & 0.088 & 0.013 \\
\hline & $40-60$ & 0.084 & 0.081 & 0.014 & 0.091 & 0.085 & 0.019 & 0.088 & 0.080 & 0.021 & 0.084 & 0.081 & 0.014 & 0.092 & 0.086 & 0.018 & 0.089 & 0.081 & 0.021 \\
\hline
\end{tabular}


Figure 3. Distribution of measured and predicted water content in the soil profile as affected by the tested treatments after 2 and $24 \mathrm{hr}$ from irrigation.

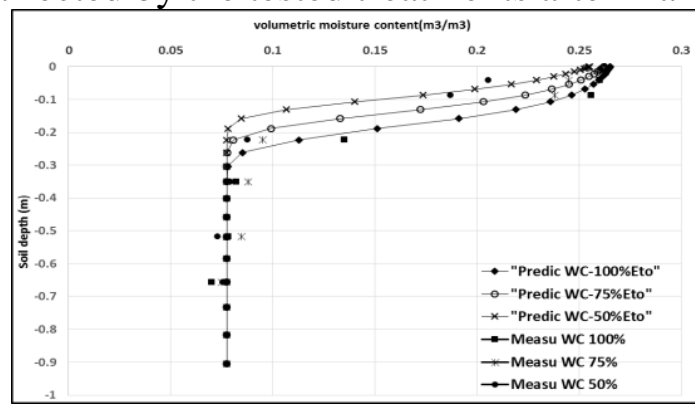

(WC after $2 \mathrm{hr}$ from irrigation for SC0)

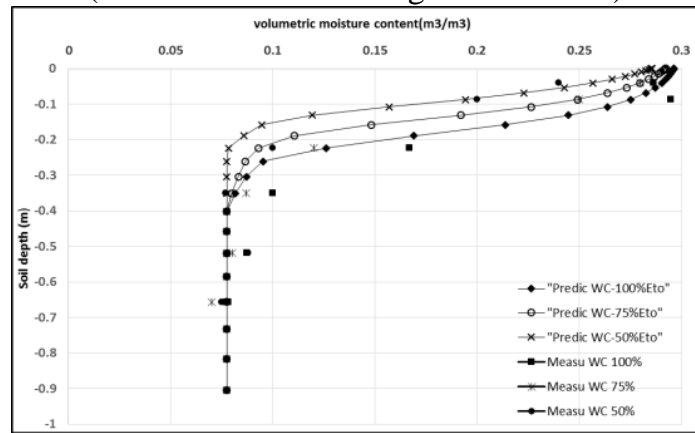

(WC after $2 \mathrm{hr}$ from irrigation for SC2)

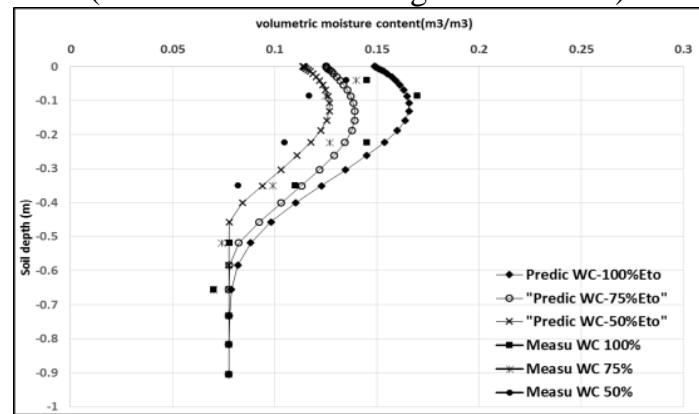

(WC after 24hr from irrigation for SC0)

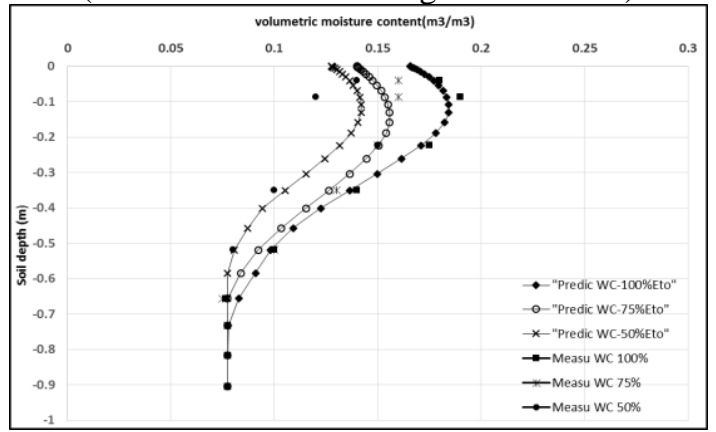

(WC after 24hr from irrigation for SC2)

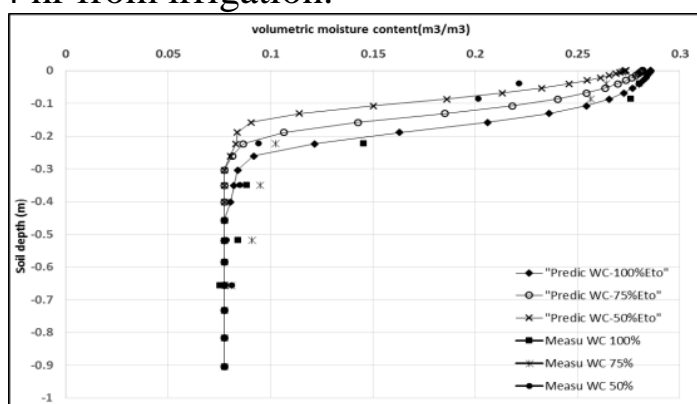

( WC after $2 \mathrm{hr}$ from irrigation for SC1)

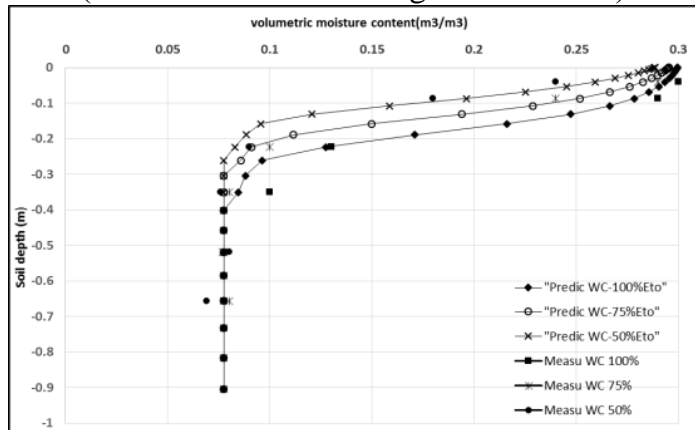

(WC after 2hr from irrigation for SC3)

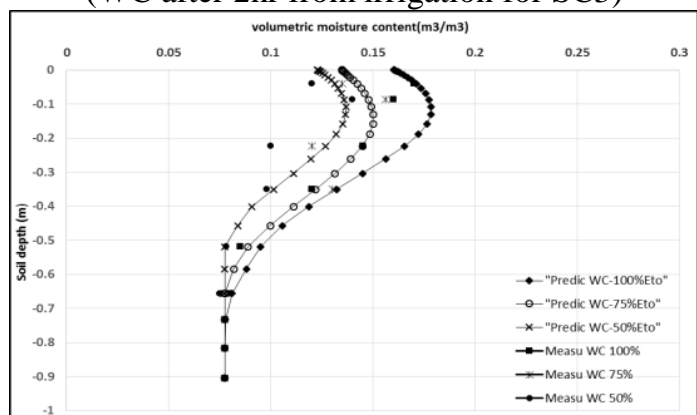

(WC after 24hr from irrigation for SC1)

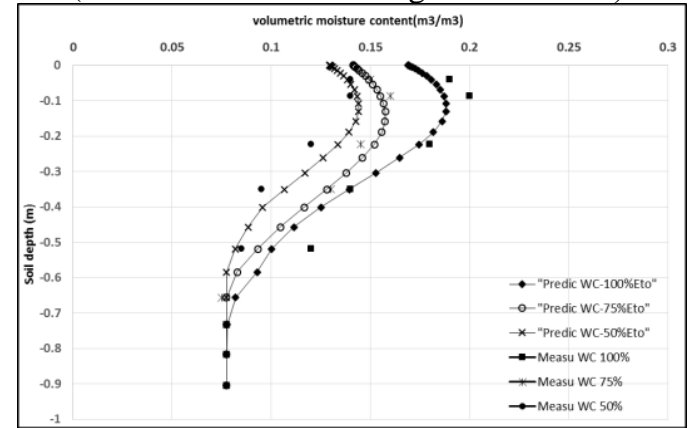

(WC after 24hr from irrigation for SC3) 
Figure 4. Distribution of measured and predicted water content in the soil profile as affected by the tested treatments after 72 and 96 hrs. from irrigation.

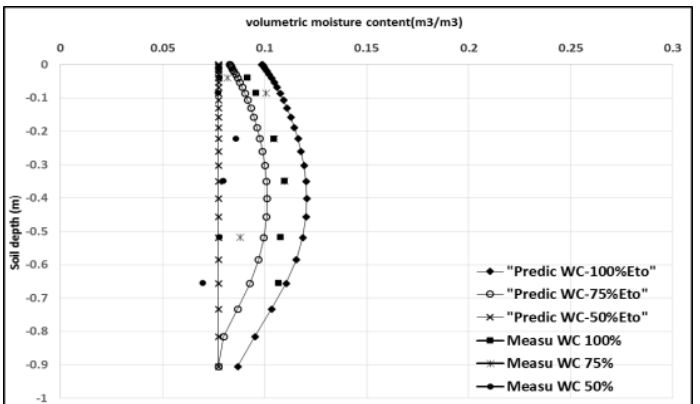

(WC after72hr from irrigation for $\mathrm{SC} 0$ )

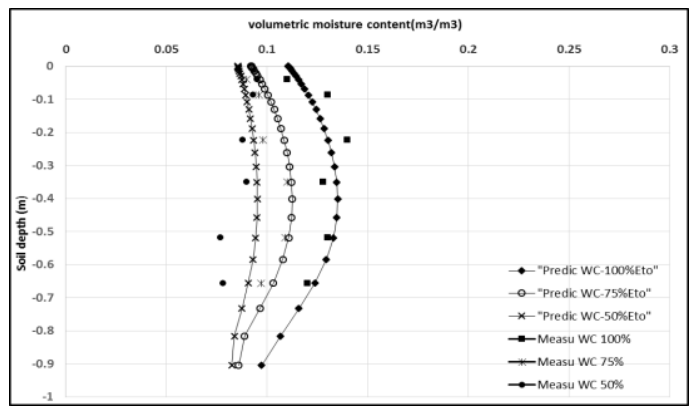

(WC after $72 \mathrm{hr}$ from irrigation for SC2)

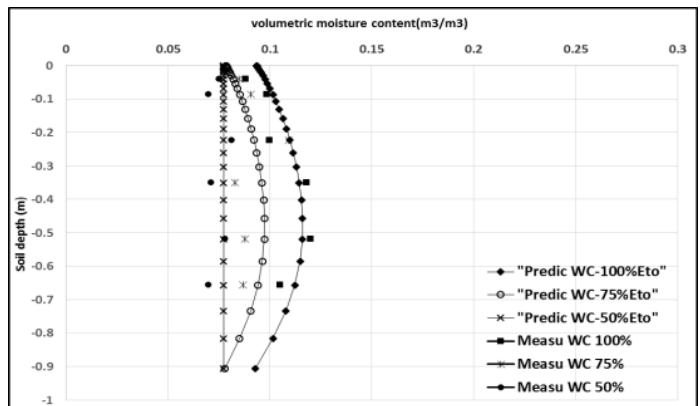

(WC after $96 \mathrm{hr}$ from irrigation for $\mathrm{SC} 0$ )

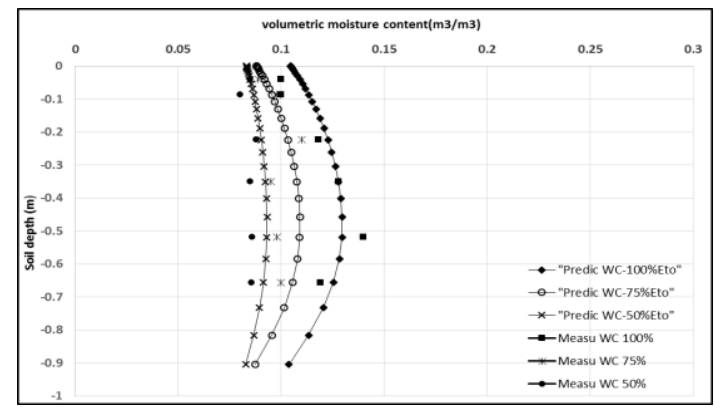

(WC after 96hr from irrigation for SC2)

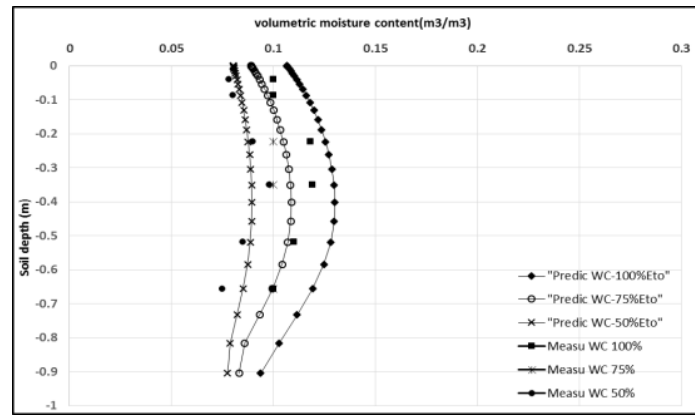

( WC after 72hr from irrigation for SC1)

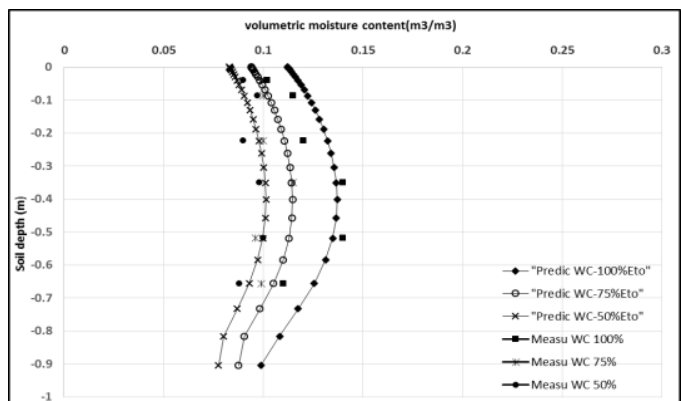

(WC after $72 \mathrm{hr}$ from irrigation for SC3)

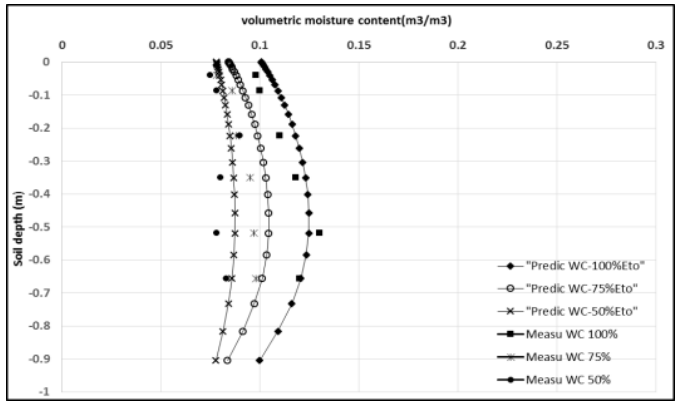

(WC after 96hr from irrigation for SC1)

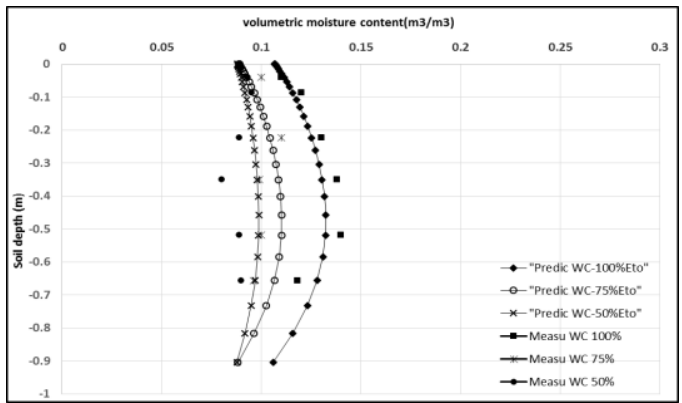

(WC after 96hr from irrigation for SC3) 
After $96 \mathrm{hrs}$., average moisture contents in the surface $20 \mathrm{~cm}$ layer were $0.106,0.114,0.119$, and $0.12 \mathrm{~m}^{3} / \mathrm{m}^{3}$ for the same respective soil conditioner treatments. Results presented in Table 6 and Figs. 3 and 4 indicated for the $100 \%$ ETo treatment that, soil moisture contents at the $40-60 \mathrm{~cm}$ layer after $96 \mathrm{hrs}$. were $0.102,0.11,0.115$, and $0.116 \mathrm{~m}^{3} / \mathrm{m}^{3}$ for the $\mathrm{SC}_{0}, \mathrm{SC}_{1}, \mathrm{SC}_{2}$, and $\mathrm{SC}_{3}$ treatments, respectively. Results showed also that, decreasing the irrigation rates decreased soil moisture contents within the soil profile.

\section{Amounts of applied irrigation water (AIW) and water consumptive use (WCU):}

Results in Table (7) show the amounts of water applied to the peanut crop during the two seasons. Results showed that the amounts of irrigation water were 3099, 2325 and $1550 \mathrm{~m}^{3} / \mathrm{fed}$ in 2015 and 2873 , 2155 and $1462 \mathrm{~m}^{3} / \mathrm{fed}$ in 2016 for the full irrigation (100\% ETo), moderate deficit ( $75 \%$ ETo) and severe deficit irrigation (50\% ETo) treatments, respectively. The amounts of water applied for full irrigation and moderate deficit agreed with those reported by Attia and Hammad (1999) and Doorenbos and Kassam (1986).

Seasonal water consumptive used (WCU) by peanut plants during the two seasons as affected by the soil conditioner and irrigation rates treatments are presented in Table (7).

Table 7. Seasonal applied water and consumptive use $\left(\mathrm{m}^{3} / \mathrm{fed}\right)$

\begin{tabular}{|c|c|c|c|c|c|c|c|c|}
\hline \multirow{2}{*}{$\begin{array}{l}\text { Irrigation } \\
\text { treatment }\end{array}$} & \multirow{2}{*}{$\begin{array}{c}\text { Soil } \\
\text { Conditioner } \\
\end{array}$} & \multicolumn{3}{|c|}{ Applied water $\left(\mathrm{m}^{3} / \mathrm{fed}\right)$} & \multicolumn{3}{|c|}{ Water consumption $\left(\mathrm{m}^{3} / \mathrm{fed}\right)$} & \multirow{2}{*}{$\begin{array}{c}\text { WCU/AIW } \\
(\%)\end{array}$} \\
\hline & & 2015 & 2016 & Average & 2015 & 2015 & Average & \\
\hline \multirow{4}{*}{$100 \%$ ETo } & $\mathrm{SC}_{0}$ & \multirow{4}{*}{3099} & \multirow{4}{*}{2873} & \multirow{4}{*}{2986} & 2759.40 & 2533.27 & 2646 & 88.6 \\
\hline & $\mathrm{SC}_{1}$ & & & & 2875.37 & 2633.36 & 2754 & 92.2 \\
\hline & $\mathrm{SC}_{2}$ & & & & 2900.86 & 2693.49 & 2797 & 93.6 \\
\hline & $\mathrm{SC}_{3}$ & & & & 2959.00 & 2853.34 & 2906 & 97.3 \\
\hline \multirow{4}{*}{$75 \%$ ETo } & $\mathrm{SC}_{0}$ & \multirow{4}{*}{2325} & \multirow{4}{*}{2155} & \multirow{4}{*}{2240} & 2110.10 & 1971.05 & 2041 & 91.1 \\
\hline & $\mathrm{SC}_{1}$ & & & & 2190.31 & 1991.13 & 2091 & 93.3 \\
\hline & $\mathrm{SC}_{2}$ & & & & 2219.69 & 2019.23 & 2119 & 94.6 \\
\hline & $\mathrm{SC}_{3}$ & & & & 2250.79 & 2051.11 & 2151 & 96.0 \\
\hline \multirow{4}{*}{$50 \%$ ETo } & $\mathrm{SC}_{0}$ & \multirow{4}{*}{1550} & \multirow{4}{*}{1462} & \multirow{4}{*}{1506} & 1462.00 & 1373.56 & 1418 & 94.2 \\
\hline & $\mathrm{SC}_{1}$ & & & & 1481.45 & 1385.61 & 1434 & 95.2 \\
\hline & $\mathrm{SC}_{2}$ & & & & 1494.71 & 1398.69 & 1447 & 96.1 \\
\hline & $\mathrm{SC}_{3}$ & & & & 1510.79 & 1403.60 & 1457 & 96.7 \\
\hline
\end{tabular}


Results indicated that, WCU increased with increasing soil conditioner and irrigation water rates. Results showed also that, average WCU values increased from 2646 to $2906 \mathrm{~m}^{3} /$ fed for the $100 \%$ ETo, and from 2041 to $2151 \mathrm{~m}^{3} /$ fed for the $75 \%$ ETo, and from 1418 to $1457 \mathrm{~m}^{3} / \mathrm{fed}$ as soil conditioner values increased from zero $\left(\mathrm{SC}_{0}\right)$ to ton/fed $\left(\mathrm{SC}_{3}\right)$. Water consumed from applied water increased with decreasing the amounts of applied water. Average WCU/AIW values were 93, 93.8, and $95.6 \%$ for the 100,75 , and $50 \%$ ETo irrigation treatments, respectively.

\section{Effect on peanut yield and yield components:}

The effect of tested treatments on pod weight ( $\mathrm{g} / \mathrm{plant}$ ), kernels weight (g/plant), 100-kernels (g), and shelling (\%) are presented in Table (8).

Table 8. Effect of tested treatments on yield components of peanut crop in the two seasons.

\begin{tabular}{|c|c|c|c|c|c|c|c|c|c|}
\hline \multirow{2}{*}{ 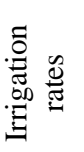 } & \multirow{2}{*}{ 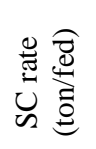 } & \multicolumn{2}{|c|}{$\begin{array}{l}\text { Pod weight } \\
\text { (g/plant) }\end{array}$} & \multicolumn{2}{|c|}{$\begin{array}{l}\text { kernels weight } \\
\text { (g/plant) }\end{array}$} & \multicolumn{2}{|c|}{$\begin{array}{l}\text { 100-kernels } \\
\text { (g) }\end{array}$} & \multicolumn{2}{|c|}{$\begin{array}{c}\text { Shelling } \\
(\%)\end{array}$} \\
\hline & & 2015 & 2016 & 2015 & 2016 & 2015 & 2016 & 2015 & 2016 \\
\hline $100 \%$ & & $77.84 \mathrm{a}$ & $78.75 a$ & $54.81 \mathrm{a}$ & $55.94 a$ & $86.44 a$ & $87.44 \mathrm{a}$ & $70.41 \mathrm{a}$ & $71.01 \mathrm{a}$ \\
\hline $75 \%$ & & $72.72 b$ & $73.84 b$ & $50.06 \mathrm{~b}$ & $51.06 \mathrm{~b}$ & $80.06 \mathrm{~b}$ & $81.56 \mathrm{~b}$ & $68.53 b$ & $68.85 b$ \\
\hline $50 \%$ & & $58.50 \mathrm{c}$ & $57.44 \mathrm{c}$ & $38.04 \mathrm{c}$ & $38.19 \mathrm{c}$ & $57.81 \mathrm{c}$ & $56.69 \mathrm{c}$ & $65.01 \mathrm{c}$ & $66.42 \mathrm{c}$ \\
\hline \multicolumn{2}{|c|}{ LSD 0.05} & 1.237 & 1.488 & 1.373 & 1.401 & 1.183 & 0.955 & 1.214 & 1.602 \\
\hline & $\mathrm{SC}_{0}$ & $63.29 \mathrm{c}$ & $61.63 \mathrm{c}$ & $42.17 \mathrm{c}$ & $41.25 \mathrm{c}$ & $68.00 \mathrm{c}$ & $66.25 \mathrm{c}$ & $66.36 \mathrm{~b}$ & $66.71 \mathrm{~b}$ \\
\hline & $\mathrm{SC}_{1}$ & $67.17 \mathrm{~b}$ & $67.42 \mathrm{~b}$ & $45.42 \mathrm{~b}$ & $46.08 \mathrm{~b}$ & $71.58 \mathrm{~b}$ & $72.00 \mathrm{~b}$ & $67.37 \mathrm{~b}$ & $68.02 \mathrm{ab}$ \\
\hline & $\mathrm{SC}_{2}$ & $73.67 \mathrm{a}$ & $75.50 \mathrm{a}$ & $51.06 \mathrm{a}$ & $53.08 \mathrm{a}$ & $79.33 a$ & $81.50 \mathrm{a}$ & $68.97 \mathrm{a}$ & $70.11 \mathrm{a}$ \\
\hline & $\mathrm{SC}_{3}$ & $74.63 \mathrm{a}$ & $75.50 \mathrm{a}$ & $51.91 \mathrm{a}$ & $53.17 \mathrm{a}$ & $80.17 \mathrm{a}$ & $81.17 \mathrm{a}$ & $69.23 a$ & $70.20 \mathrm{a}$ \\
\hline \multicolumn{2}{|c|}{ LSD 0.05} & 1.203 & 1.575 & 1.151 & 1.524 & 1.239 & 1.206 & 1.300 & 2.522 \\
\hline \multirow[t]{4}{*}{$100 \%$} & $\mathrm{SC}_{0}$ & 71.38 & 69.75 & 50.25 & 49.00 & 80.75 & 78.75 & 65.04 & 70.25 \\
\hline & $\mathrm{SC}_{1}$ & 76.00 & 77.00 & 53.25 & 54.75 & 83.75 & 85.75 & 70.06 & 71.13 \\
\hline & $\mathrm{SC}_{2}$ & 82.50 & 84.25 & 57.25 & 60.00 & 90.00 & 92.75 & 70.25 & 71.22 \\
\hline & $\mathrm{SC}_{3}$ & 82.50 & 84.00 & 58.5 & 60.00 & 91.25 & 92.50 & 70.92 & 71.44 \\
\hline \multirow[t]{4}{*}{$75 \%$} & $\mathrm{SC}_{0}$ & 64.00 & 62.13 & 41.00 & 40.25 & 70.25 & 68.75 & 64.02 & 64.81 \\
\hline & $\mathrm{SC}_{1}$ & 68.25 & 69.00 & 45.75 & 47.00 & 74.75 & 75.75 & 67.00 & 68.09 \\
\hline & $\mathrm{SC}_{2}$ & 78.50 & 82.25 & 56.25 & 58.50 & 87.00 & 91.75 & 71.65 & 71.15 \\
\hline & $\mathrm{SC}_{3}$ & 80.13 & 82.00 & 57.25 & 58.50 & 88.25 & 90.75 & 71.44 & 71.33 \\
\hline \multirow[t]{4}{*}{$50 \%$} & $\mathrm{SC}_{0}$ & 54.5 & 53.00 & 35.25 & 34.50 & 53.00 & 51.25 & 64.65 & 65.05 \\
\hline & $\mathrm{SC}_{1}$ & 57.25 & 56.25 & 37.25 & 36.50 & 56.25 & 54.50 & 65.04 & 64.86 \\
\hline & $\mathrm{SC}_{2}$ & 61.00 & 60.00 & 39.68 & 40.75 & 61.00 & 60.75 & 65.02 & 67.95 \\
\hline & $\mathrm{SC}_{3}$ & 61.25 & 60.50 & 40.00 & 41.00 & 61.00 & 60.25 & 65.33 & 67.82 \\
\hline \multicolumn{2}{|c|}{ LSD 0.05} & $* * *$ & $* * *$ & $* * *$ & $* * *$ & $* * *$ & $* * *$ & $* * *$ & $* * *$ \\
\hline
\end{tabular}


Results showed that, there were significant effect of irrigation rates and soil conditioner levels on the tested parameters. Decreasing the amounts of applied irrigation water, significantly decreased all the tested parameters. As for soil conditioner levels, there was no significant difference between $\mathrm{SC}_{3}$ and $\mathrm{SC}_{2}$ levels, while they both differed significantly with $\mathrm{SC}_{1}$ and $\mathrm{SC}_{0}$ levels. The interaction between $100 \%$ ETo and $\mathrm{SC}_{2}$ treatments recorded the highest pod weight/plant of 82.5 and $84.25 \mathrm{~g} / \mathrm{plant}$ in the 2015 and 2016 seasons, respectively. The same treatments achieved the highest kernel weight per plant of 58.5 and 60 $\mathrm{g} /$ plant in the same respective seasons. The highest 100-kernel weight of 91.25 and $92.75 \mathrm{~g}$ were recorded for the interaction between $100 \%$ ETo and $\mathrm{SC}_{3}$ and the $100 \%$ ETo and $\mathrm{SC}_{2}$ treatments in the two seasons, respectively. As for the shelling \%, the highest values of 70.92 and $71.44 \%$ were recorded for the $100 \%$ ETo and $\mathrm{SC}_{3}$ treatment in the two seasons. The lowest values of the previous parameters were recorded for the interaction between $50 \%$ ETo and $\mathrm{SC}_{0}$ treatments in both seasons.

The effect of irrigation rates and soil conditioner levels on kernel protein and straw protein, pod and straw yields in the two growing seasons is presented in Table (9). Results indicated, in general that, there was a significant effect of the tested treatments on the abovementioned parameters. All the tested parameters were significantly different at each irrigation rate, with highest values at $100 \%$ ETo rate and lowest values at the $50 \%$ rate in the two seasons. As for soil conditioner effect, results showed no significant difference between $\mathrm{SC}_{2}$ and $\mathrm{SC}_{3}$ rates on pod and straw yields, while they both differed than $\mathrm{SC}_{1}$ and $\mathrm{SC}_{0}$ rates. This trend was not the same for kernel and straw proteins. The interaction $100 \%$ ETo $* \mathrm{SC}_{3}$ the highest values of 29.75 and $28.5 \%$ for the kernel protein parameter in the two seasons, and the value of $15.13 \%$ for the straw protein in the 2015 season. While, the interaction $100 \%$ ETo $* \mathrm{SC}_{2}$ recorded the highest value of $14.34 \%$ for the straw protein parameter in the 2016 season. The same interaction recorded the highest pod yields of 1.83 and 1.89 ton/fed and the straw yields of 1.31 and 1.32 ton/fed in the 2015 and 2016 growing seasons, respectively.

Results showed also that, the interaction between 50\% ETo * SC0 recorded the lowest values of kernel and straw proteins and pod and 
straw yields in the two seasons. The obtained results of peanuts yield components were consistent with those reported by El-Shafei et al., (2008), Abdrabbo, (2009) and Badawi et al., (2011).

Table 9. Effect of the tested treatments on kernel and straw proteins and on pod and straw yields in the two seasons.

\begin{tabular}{|c|c|c|c|c|c|c|c|c|c|}
\hline \multirow{2}{*}{ 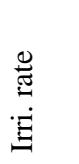 } & \multirow{2}{*}{ 总 } & \multicolumn{2}{|c|}{$\begin{array}{l}\text { Kernels protein } \\
(\%)\end{array}$} & \multicolumn{2}{|c|}{$\begin{array}{c}\text { Straw protein } \\
(\%)\end{array}$} & \multicolumn{2}{|c|}{$\begin{array}{c}\text { Pod yield } \\
\text { (Mg/fed) }\end{array}$} & \multicolumn{2}{|c|}{$\begin{array}{l}\text { Straw yield } \\
(\mathrm{Mg} / \mathrm{fed})\end{array}$} \\
\hline & & 2015 & 2016 & 2015 & 2016 & 2015 & 2016 & 2015 & 2016 \\
\hline $100 \%$ & & $28.50 \mathrm{a}$ & $27.69 \mathrm{a}$ & $14.76 \mathrm{a}$ & $14.48 \mathrm{a}$ & $1.65 \mathrm{a}$ & $1.67 \mathrm{a}$ & $1.18 \mathrm{a}$ & $1.22 \mathrm{a}$ \\
\hline $75 \%$ & & $25.30 \mathrm{~b}$ & $25.19 b$ & $13.24 b$ & $13.13 b$ & $1.42 \mathrm{~b}$ & $1.48 \mathrm{~b}$ & $1.03 b$ & $1.06 \mathrm{~b}$ \\
\hline $50 \%$ & & $21.13 \mathrm{c}$ & $20.47 \mathrm{c}$ & $11.74 \mathrm{c}$ & $11.38 \mathrm{c}$ & $1.05 \mathrm{c}$ & $1.02 \mathrm{c}$ & $0.78 \mathrm{c}$ & $0.80 \mathrm{c}$ \\
\hline \multicolumn{2}{|c|}{ LSD 0.05} & 0.620 & 0.731 & 0.419 & 0.419 & 0.048 & 0.046 & 0.042 & 0.049 \\
\hline & $\mathrm{SC}_{0}$ & $23.1 \mathrm{~b}$ & $22.00 \mathrm{c}$ & $12.41 \mathrm{c}$ & $12.12 \mathrm{~b}$ & $1.09 \mathrm{c}$ & $1.09 \mathrm{c}$ & $0.76 \mathrm{c}$ & $0.78 \mathrm{c}$ \\
\hline & $\mathrm{SC}_{1}$ & $23.71 \mathrm{~b}$ & $23.71 \mathrm{~b}$ & $12.81 \mathrm{c}$ & $12.92 \mathrm{a}$ & $1.25 \mathrm{~b}$ & $1.18 \mathrm{~b}$ & $0.95 \mathrm{~b}$ & $0.98 \mathrm{~b}$ \\
\hline & $\mathrm{SC}_{2}$ & $26.21 \mathrm{a}$ & $25.92 \mathrm{a}$ & $13.55 \mathrm{~b}$ & $13.44 \mathrm{a}$ & $1.59 \mathrm{a}$ & $1.66 \mathrm{a}$ & $1.14 \mathrm{a}$ & $1.17 \mathrm{a}$ \\
\hline & $\mathrm{SC}_{3}$ & $26.88 \mathrm{a}$ & $26.17 \mathrm{a}$ & $14.21 \mathrm{a}$ & $13.49 \mathrm{a}$ & $1.58 \mathrm{a}$ & $1.63 \mathrm{a}$ & $1.14 \mathrm{a}$ & $1.16 \mathrm{a}$ \\
\hline \multicolumn{2}{|c|}{ LSD 0.05} & 0.963 & 1.090 & 0.573 & 0.647 & 0.068 & 0.066 & 0.071 & 0.081 \\
\hline \multirow[t]{4}{*}{$100 \%$} & $\mathrm{SC}_{0}$ & 27.75 & 25.75 & 14.63 & 14.31 & 1.44 & 1.47 & 1.02 & 1.03 \\
\hline & $\mathrm{SC}_{1}$ & 28.00 & 28.00 & 14.76 & 14.95 & 1.59 & 1.46 & 1.14 & 1.20 \\
\hline & $\mathrm{SC}_{2}$ & 28.5 & 28.5 & 14.5 & 14.34 & 1.83 & 1.89 & 1.31 & 1.32 \\
\hline & $\mathrm{SC}_{3}$ & 29.75 & 28.50 & 15.13 & 14.30 & 1.75 & 1.85 & 1.25 & 1.33 \\
\hline \multirow[t]{4}{*}{$75 \%$} & $\mathrm{SC}_{0}$ & 23.49 & 22.75 & 12.33 & 12.03 & 1.05 & 1.04 & 0.69 & 0.69 \\
\hline & $\mathrm{SC}_{1}$ & 23.94 & 24.63 & 12.99 & 13.20 & 1.25 & 1.22 & 1.00 & 1.04 \\
\hline & $\mathrm{SC}_{2}$ & 26.50 & 26.63 & 13.38 & 13.73 & 1.69 & 1.84 & 1.22 & 1.25 \\
\hline & $\mathrm{SC}_{3}$ & 27.25 & 26.75 & 14.25 & 13.55 & 1.71 & 1.81 & 1.23 & 1.24 \\
\hline \multirow[t]{4}{*}{$50 \%$} & $\mathrm{SC}_{0}$ & 18.09 & 17.50 & 10.26 & 10.03 & 0.78 & 0.78 & 0.57 & 0.62 \\
\hline & $\mathrm{SC}_{1}$ & 19.19 & 18.50 & 10.68 & 10.60 & 0.91 & 0.87 & 0.71 & 0.70 \\
\hline & $\mathrm{SC}_{2}$ & 23.63 & 22.63 & 12.79 & 12.25 & 1.24 & 1.24 & 0.89 & 0.94 \\
\hline & $\mathrm{SC}_{3}$ & 23.63 & 23.25 & 13.25 & 12.63 & 1.29 & 1.22 & 1.23 & 0.91 \\
\hline \multicolumn{2}{|c|}{ LSD 0.05} & **** & ** & *** & **** & *** & **** & $* * *$ & ** \\
\hline
\end{tabular}

\section{Effect on water productivity (WP):}

The effect of tested treatments on water productivity of peanut crop is presented in Table (9). Results indicated that WP values were significantly affected by both irrigation rates and soil amendment treatments. Results revealed that, decreasing the amounts of applied water, increased the WP values. While, increasing the soil conditioner rates increased the WP values The lowest WP values of 0.53 and $0.58 \mathrm{~kg}$ pods $/ \mathrm{m}^{3}$ of applied water were obtained from plots received full irrigation (100\% ETo) in the 2015 and 2016 seasons, respectively. Also, the lowest values of $0.38 \mathrm{~kg}$ straw $/ \mathrm{m}^{3}$ and $0.42 \mathrm{~kg}$ straw $/ \mathrm{m}^{3}$ of applied water were recorded for the respective two seasons. 
Table 10. Water productivity as affected by the different soil conditioner levels and irrigation rates

\begin{tabular}{|c|c|c|c|c|c|}
\hline \multirow{2}{*}{ 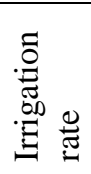 } & \multirow{2}{*}{ 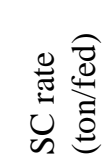 } & \multicolumn{2}{|c|}{$\begin{array}{l}\text { Water productivity } \\
\left(\mathrm{kg} \mathrm{pod} / \mathrm{m}^{3}\right)\end{array}$} & \multicolumn{2}{|c|}{$\begin{array}{c}\text { Water productivity } \\
\left(\mathrm{kg} \text { straw } / \mathrm{m}^{3}\right)\end{array}$} \\
\hline & & 2015 & 2016 & 2015 & 2016 \\
\hline $100 \%$ & & $0.53 c$ & $0.58 \mathrm{c}$ & $0.38 \mathrm{c}$ & $0.42 \mathrm{c}$ \\
\hline $75 \%$ & & $0.61 \mathrm{~b}$ & $0.69 \mathrm{~b}$ & $0.44 \mathrm{~b}$ & $0.49 b$ \\
\hline $50 \%$ & & $0.68 \mathrm{a}$ & $0.71 \mathrm{a}$ & $0.50 \mathrm{a}$ & $0.55 a$ \\
\hline \multicolumn{2}{|c|}{ LSD 0.05} & 0.0215 & 0.0210 & 0.0236 & 0.030 \\
\hline & $\mathrm{SC}_{0}$ & $0.47 \mathrm{c}$ & $0.51 \mathrm{c}$ & $0.33 c$ & $0.37 \mathrm{c}$ \\
\hline & $\mathrm{SC}_{1}$ & $0.54 \mathrm{~b}$ & $0.56 \mathrm{~b}$ & $0.42 \mathrm{~b}$ & $0.46 \mathrm{~b}$ \\
\hline & $\mathrm{SC}_{2}$ & $0.71 \mathrm{a}$ & $0.79 \mathrm{a}$ & $0.50 \mathrm{a}$ & $0.56 \mathrm{a}$ \\
\hline & $\mathrm{SC}_{3}$ & $0.71 \mathrm{a}$ & $0.78 \mathrm{a}$ & $0.51 \mathrm{a}$ & $0.56 \mathrm{a}$ \\
\hline \multicolumn{2}{|c|}{ LSD 0.05} & 0.0327 & 0.0305 & 0.0373 & 0.0497 \\
\hline \multirow[t]{4}{*}{$100 \%$} & $\mathrm{SC}_{0}$ & 0.46 & 0.51 & 0.33 & 0.36 \\
\hline & $\mathrm{SC}_{1}$ & 0.51 & 0.51 & 0.37 & 0.42 \\
\hline & $\mathrm{SC}_{2}$ & 0.59 & 0.66 & 0.42 & 0.46 \\
\hline & $\mathrm{SC}_{3}$ & 0.65 & 0.65 & 0.40 & 0.46 \\
\hline \multirow[t]{4}{*}{$75 \%$} & $\mathrm{SC}_{0}$ & 0.45 & 0.48 & 0.30 & 0.32 \\
\hline & $\mathrm{SC}_{1}$ & 0.54 & 0.57 & 0.43 & 0.48 \\
\hline & $\mathrm{SC}_{2}$ & 0.72 & 0.86 & 0.52 & 0.58 \\
\hline & $\mathrm{SC}_{3}$ & 0.73 & 0.84 & 0.53 & 0.58 \\
\hline \multirow[t]{4}{*}{$50 \%$} & $\mathrm{SC}_{0}$ & 0.50 & 0.54 & 0.37 & 0.43 \\
\hline & $\mathrm{SC}_{1}$ & 0.58 & 0.61 & 0.45 & 0.49 \\
\hline & $\mathrm{SC}_{2}$ & 0.80 & 0.86 & 0.57 & 0.65 \\
\hline & $\mathrm{SC}_{3}$ & 0.83 & 0.85 & 0.61 & 0.63 \\
\hline \multicolumn{2}{|c|}{ LSD 0.05} & $* * *$ & $* * *$ & $* * *$ & $* * *$ \\
\hline
\end{tabular}

As deficiency of irrigation water intensified, WP improved and reached $0.68 \mathrm{~kg}$ pods $/ \mathrm{m}^{3}$ and $0.71 \mathrm{~kg}$ pods $/ \mathrm{m}^{3}$ as well as $0.50 \mathrm{~kg}$ straw $/ \mathrm{m}^{3}$ and $0.55 \mathrm{~kg}$ straw $/ \mathrm{m}^{3}$ in 2015 and 2016 seasons, respectively.

As for soil conditioner, increasing the SC rates from zero to 3 ton/fed increased the WP values from 0.47 to $0.71 \mathrm{~kg}$ pods $/ \mathrm{m}^{3}$ in 2015 and from 0.51 to $0.79 \mathrm{~kg}$ pods $/ \mathrm{m}^{3}$ in 2016 . The same trend was recorded for the WP of straw yield. The $\mathrm{Wp}$ values increased from 0.33 to $0.51 \mathrm{~kg} \mathrm{straw} / \mathrm{m}^{3}$ in 2015 and from 0.37 to $0.56 \mathrm{~kg}$ straw $/ \mathrm{m}^{3}$ in 2016. Results in Table (9) showed significant interaction between irrigation rate and soil conditioner on WP values. The values of water productivity for different treatments agreed with those obtained by El-Shafei et al., (2008), Yinhong et al., (2009) and Xiaolin et al., (2015). 


\section{CONCLUSIONS}

From the obtained results it could be concluded that:

- The addition of the soil conditioner to sandy soil improves its water storage capability and decreases its saturated hydraulic conductivity.

- The tested simulation model proved to be accurate to predict changes in soil moisture contents with time as well as moisture distribution within the soil profile.

- Applying amount of irrigation water equals to $100 \%$ ETo with 2 ton/fed of hydro-gel soil conditioner will produce the highest pod and straw yields of peanut crop grown in sandy soil.

- In the sandy soil, an average water productivity value of $0.65 \mathrm{~kg}$ $\mathrm{pod} / \mathrm{m}^{3}$ and $0.43 \mathrm{~kg}$ straw $/ \mathrm{m}^{3}$ can be achieved from the interaction between $100 \%$ ETo $* \mathrm{SC}_{2}$ treatment.

\section{REFERENCES}

Abdrabbo A. Abou Kheira, 2009. Macro-management of deficit-irrigated peanut with sprinkler irrigation. Agricultural Water Management 96 (2009) 1409-1420.

Allam; Kh. A., 2004. Simulation model of water movement in sandy soils under trickle irrigation conditions. Ph.D. Alex. Uni. Fac. of Agri. Saba Basha: 32-50.

Al-Omran A M.; A. R. Al-harbi; M. A. Wahb-allah; M. Nadeem; and A. Al-eter., 2010. Impact of irrigation water quality, irrigation systems, irrigation rates and soil amendments on tomato production in sandy calcareous soil. Turkish Journal of Agriculture and Forestry 34 (2010): 59-73

Andry H.; T. Yamamotoa; T. Iriea; S. Moritania; M. Inouea and H. Fujiyama., 2009 Water retention, hydraulic conductivity of hydrophilic polymers in sandy soil as affected by temperature and water quality. Journal of Hydrology 373 (2009) 177-183

ASAE standard. 1988. Procedure for sprinkler distribution testing for research proposes. ASAE stdd. 35th Ed., ASAE: 501-503.

Attia, M.M. and K.M. Hammad., 1999. Drip irrigation scheduling of peanut in sandy soils. Mansoura Univ. J. Ag. Sci. 24 (11): 70597069.

Badawi F.Sh.F., A.M.M. Biomy and A.H. Desoky, 2011. Peanut plant growth and yield as influenced by co-inoculation with 
Bradyrhizobium and some rhizo-microorganisms under sandy loam soil conditions. Faculty of Agriculture, Ain Shams University. Annals of Agricultural Science (2011) 56, $17-25$

Beheiry, G.; Gh. S.; Soilman, A.A.; Nadia, F.; El-Aasar and I.H.; ElBagouri., 1997. Accumulation and residual effects of natural amendments on chemical properties of some desert soil under saline water irrigation. International Symposium of Salt Affected Soils, pp. 395-405.

Benami, I. and A. Ofen., 1984. Irrigation Engineering. Irrigation Engineering Publications (IESP), Haifa, Israel.

Bhardwaj, A.K.; I.; Shainberg, D.; Goldstein, D.N.; Warrington and G.J.; Levy., 2007. Water retention and hydraulic conductivity of crosslinked polyacrylamides in sandy soils. Soil Science Society of America Journal 71, 406-412.

Brouwer, C.; K. Prins and M. Heibloem., 1989. Irrigation water management: irrigation scheduling. Training manual no. 4 chapter 3 FAO, Rome, Italy, 28-29.

Black, C. A.; D. D. Evans; L. E. Ensminger; J. L. White; F. E. Clark and R. C. Dinauer., 1985. Methods of soil analyses. Seven Printing. Amer. Soc. of Agro. Madison, Wisconsin USA. 425-455

Bogino, P.; E. Banchio; L. Rinaudi; G. Cerioni; C. Bonfiglio and W. Giordano., 2006. Peanut (Arachis hypogaea) response to inoculation with Bradyrhizobium sp. In soils of Argentina. Ann. Appl. Biol. 148, 207-212.

Borg, H. and D. Grimes. 1986. Depth development of roots with time: an empirical description. Trans. ASAE 29, 194-197.

Bouranis D.L.; A. G. Theodoropoulus and J.B. Drossopoulus., 1995. Designing synthetic polymers as soil conditioners. Commune Soil Sci Plant Anal 26:1455-1480.

CoHort Software. 2005. Costat Statistical package (version 6.311), P.O.Box 1149, Berkeley, CA, 94701, USA.

Chatzoudis G. K. and F. Rigas., 1999. Soil salts reduce hydration of polymeric gels and affect moisture characteristics of soil. Commune Soil Sci Plant Anal 30:2465-2474

Doorenbos, J. and W. O. Pruitt., 1977. Guidelines for predicting crop water 
requirements. FAO Irrig. Drain. Paper no: 24, FAO, Rome, Italy, p. 97-100.

Doorenbos, J. and A. H Kassam., 1986. Yield response to water. FAO Irrig. Drain. Paper no: 33, FAO, Rome, Italy, p. 97-100

Doorenbos, J. and W. O. Pruitt., (1992). Calculation of Crop Water Requirement. In CropWater Requirement. FAO of The United Nation, Rome, Italy, pp. 1-65.

El-Shafei A.; Kh. A. Allam and T. K. Zin El-Abedin., 2008. Heterogeneity analysis of sprinkler irrigation in peanut fields. Misr J. Ag. Eng., 25(1): 58- 86

El-Maghraby, S.E.; F.A.; Hashem and M.M.; Wassif., 1996. The use of sulphur and organic manure for controlling soil salinity pollution under high saline water irrigation. Egypt J. Soil Sci., 36, 269-288.

Günes T. 2007. Effect of polymer on seedlings survival and growth of transplanted tomato under water stress. Asian J Chem 19(4):32083214

Han, Y.G.; P.L. Yang; Y.P Luo; S.M. Ren; L.X. Zhang and L. Xu, 2010. Porosity change model for watered super absorbent polymer-treated soil. Environ. Earth Sci. 61, 1197-1205.

Keller, J. and R. D. Bliesner. 1990. Sprinkle and trickle irrigation, Van Nostrand Reinhold, New York, ISBN: 0-442-24645-5.

Khalifa, H.E.; A.M, El-Gindy; G.A. Sharaf and Kh. A. Allam. 2004. Simulation water movement in sandy soil under surface point- source emitter: I-Model development. . Misr J. Ag. Eng., 21(2) 341-361

Ismail, S. M. 2002. Design and Management of Field Irrigation System. (in Arabic) Monshaet Al-Maaref Alex., 1st Ed.: 167-168.

Leciejewski, P. 2009. The effect of hydrogel additives on the water retention curve of sandy soil from forest nursery in Julinek. J. Water Land Dev. No. 13a, 2009: 239-247

Lixia Y., Y. Yangb, Z. Chena, C. Guoc, and S. Li 2014. Influence of super absorbent polymer on soil water retention, seed germination and plant survivals for rocky slopes eco-engineering. Ecological Engineering 62 (2014) 27- 32

Molden D. 2003. A water-productivity framework for understanding and action.In: Kijne, J.W., Barker, R Molden, D. (Eds.), Water 
Productivity in Agriculture:Limits and Opportunities for Improvement .International Water Management Institute, Colombo, Sri Lanka, pp. 1-18.

Salem N., A. Khater, M.Y. Tayel, and M.A. Matyn, 1990. Effect of soil amendments, irrigation and seeding density on growth of peas and nutrient uptake. SOIL TECHNOLOGY vol. 3, p. 301-309

Simonne, E. H. and M. D. Dukes, 2010. Principles and practices of irrigation management for vegetables. University of Florida, Hort. Sci. Extension. pp 17-23.

USDA, (2016). Production Estimates and Crop Assessment Division, Foreign Agr. Service, Circular Series FAS, USDA, WAP 11-16, November 2016.

Vara Prasad P.V., V. G. Kakani and H. D. Upadhyaya., 2011. Growth and production of groundnut. Soils and plant growth and crop production vol II

Viero P.W.M.,, K.M. Little, and D.G. Oscroft., 2000. The effect of a soil amended hydrogel on the establishment of a Eucalyptus grandis $\mathrm{x}$ E. amaldulens is clone grown on the sandy soils of Zululand. Southern Afr For J 188:21-28

Viero P.W.M., K.E.A. Chiswell, J.M. Theron., 2002. The effect of a soilamended hydrogel on the establishment of a Eucalyptus grandis clone on a sandy clay loam soil in Zululand during winter. Southern Afr For J 193:65-75

Wassif, M.M., S.E. El-Maghraby, and A.H. Frah, 1997. Application of soil amendments as management practices for sustainable productivity under irrigation with saline water. International Symposium of Salt Affected Soils., pp.328-333.

Xiaolin Y., Y. Chen, S. Pacenk, W. Gao, L, Maa, G. Wanga, P. Yan, P .Sui and S. T. Steenhuis, 2015. Effect of diversified crop rotations on groundwater levels and crop water productivity in the North China Plain. Journal of Hydrology 522 (2015) 428-438.

Yinhong K., S. Khan and X., Ma, 2009. Climate change impacts on crop yield, crop water productivity and food security - A review. Progress in Natural Science 19 (2009) 1665-1674.

Zohuriaan-M, M.J. and K., Kabiri, 2008. Superabsorbent polymer materials: a review. Iran. Polym. J. 17, 451-477. 


\section{الملخص العربي}

\section{تأثير محسن التربة علي المحتوي الرطوبي للأرض الرملية وإنتاجية الفول السوداني تحت معدلات مياه ري مختلفة لالرية}

\section{خليل عبدالحليم علام' مان}

للدراسة تأثير إضافة محسن للتربة على المحتوى الرطوبي للتربة الرملية و إنتاجية الفول

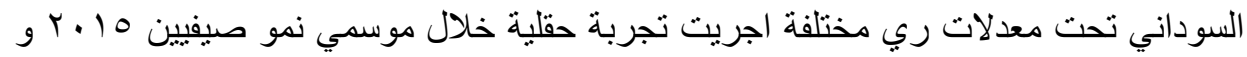

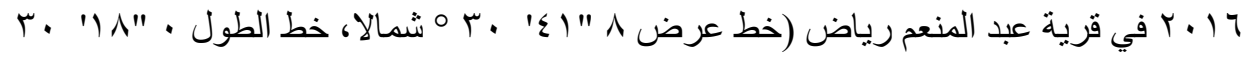

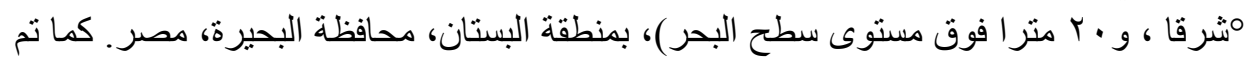

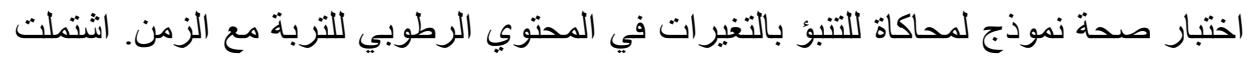

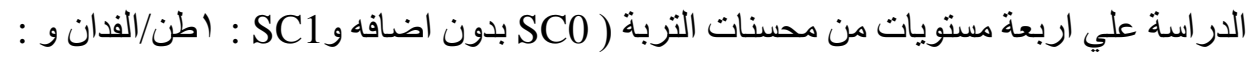

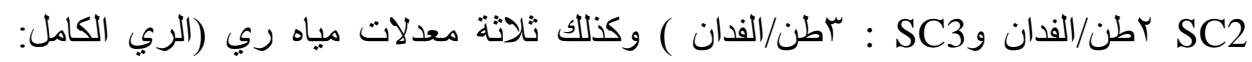

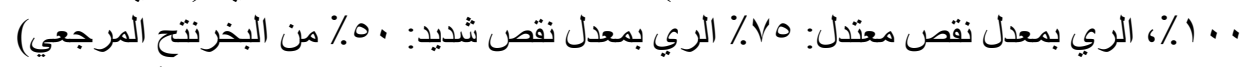

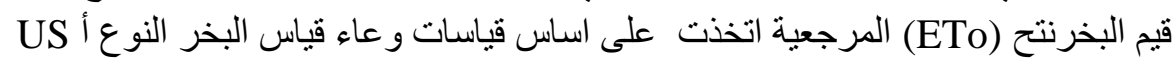
Class A-Pan.

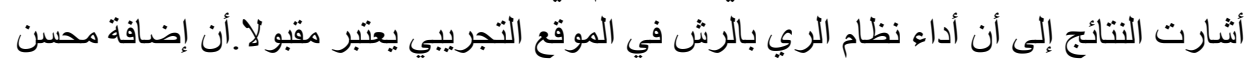

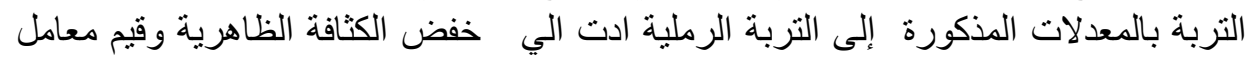

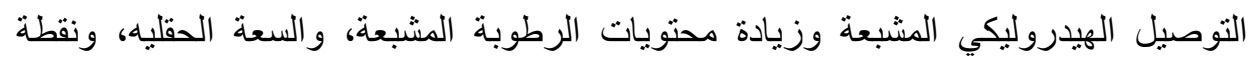

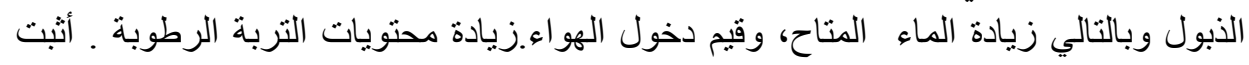

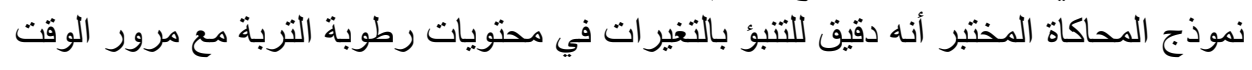

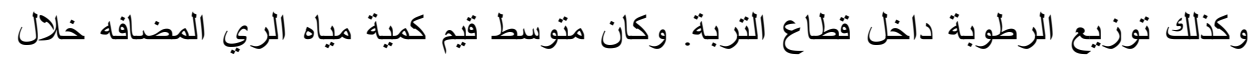

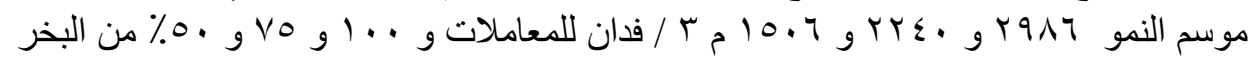

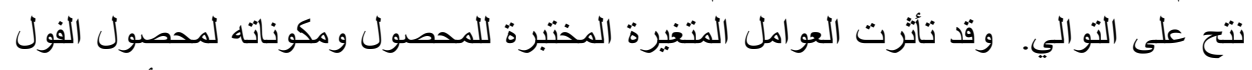

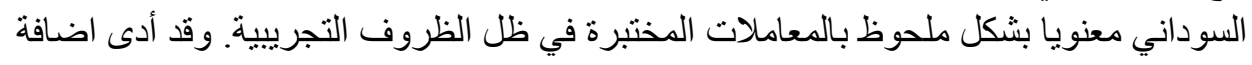

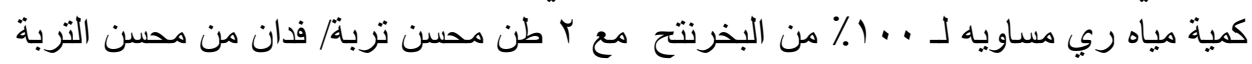

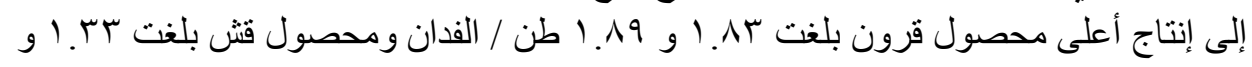

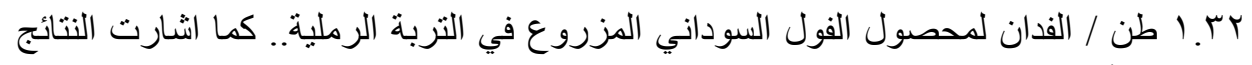

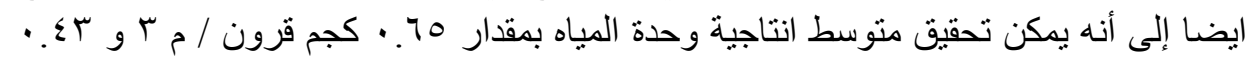

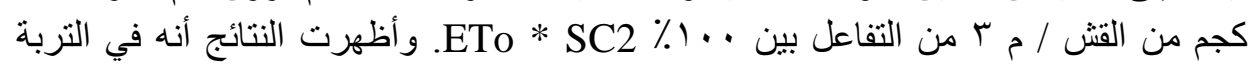

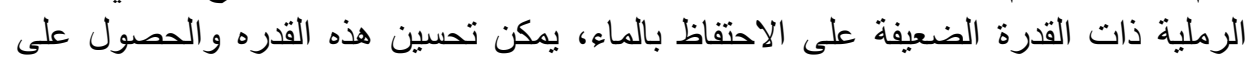

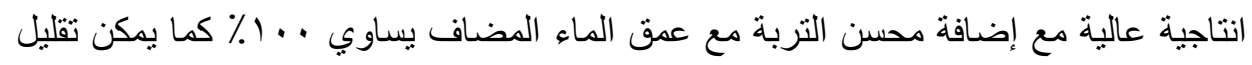

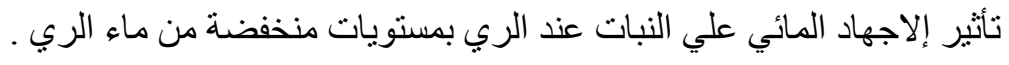

1 باحث اول - معهد بحوث الهندسة الزراعية مركز البحوث الزراعية ـ وزارة الزراعة ـ شارع نادي الصيد ـ الاقي - جيزة . 